\title{
Construction Labour Productivity as a Correlate of Project Performance: An Empirical Evidence for Wall Plastering Activity
}

\author{
Odesola, I.A. ${ }^{1}$
}

\begin{abstract}
Construction labour productivity has always been believed to be associated with project performance but empirical evidence for this assertion is scarce in literature. This study aims at determining the relationship between construction labour productivity and project performance. Hence, the study evaluates: construction labour productivity, time and cost overruns in wall plastering activity of selected completed public building projects. A survey of 180 purposively sampled public building projects was conducted. Data were collected through project inventory sheet and analysed using ANOVA and Pearson Product Moment Correlation. The results indicate that there is a strong negative correlation between construction labour productivity and cost and time overruns. It also shows that there is no variation in cost and time overruns among the states in the study area. The study therefore, recommends that stakeholders in the construction industry should emphasis the use of productivity improvement strategies on building sites to enhance project performance.
\end{abstract}

Keywords: Construction; labour; project performance; productivity; public building projects; Nigeria.

\section{Introduction}

Productivity is considered as one of the most important factors that affect the success and overall performance of every organization, whether large or small, in today's competitive market [1]. However, Park et al. [2] identify construction productivity as a cause of great concern. Veiseth et al. [3] and Hewage and Ruwanpura [4] observe that for decades, many researchers have reported the decline in construction productivity. Lawal [5] reports that in Nigeria, construction workers in the public service have almost zero productivity while Kaming et al. [6] identify poor productivity of craftsmen as one of the most daunting problems confronting the construction industry especially in developing countries. In view of this, there is a growing and continuous interest in productivity studies all over the world because of its contribution to project cost. Hendrickson and Au [7] state that "good project management in construction must vigorously pursue the efficient utilization of labour, material and equipment and that improvement of labour productivity should be a major and continuous concern of those who are responsible for cost control of constructed facilities".

${ }^{1}$ Department of Building, University of Uyo, Uyo, Akwa-Ibom State, NIGERIA. E-mail: isaacodesola@yahoo.co.uk

Note: Discussion is expected before June, $1^{\text {st }} 2015$, and will be published in the "Civil Engineering Dimension" volume 17, number 2, September 2015.

Received 31 December 2013; revised 29 May 2014; accepted 02 November 2014
The reported low productivity in the construction industry is accompanied with its attendant problems of project time and cost overruns, disputes, project abandonment among other problems. According to Aibinu and Jagboro [8], a major criticism facing the Nigerian construction industry is the growing rate of delay in project delivery. Project abandonment is another issue that cannot be ignored on construction sites. Nwachukwu et al. [9] maintain that project failure and abandonment are common phenomena in the Nigerian economy.

Studies on cost and time overruns in construction projects have discovered that the construction industry in both developed and developing countries suffers from delays and cost overruns due to labour productivity problems $[6,10]$. However, despite the many suggestions and opinions in literature concerning the relationship between construction labour productivity and project performance, empirical evidence for these assertions are scarce. The problem of this study is therefore concerned with determining, empirically, the influence of construction labour productivity on the time and cost performance of public building projects. Based on this understanding, this study attempts to investigate the contribution of labour productivity to project performance. The overall aim is to provide empirical evidence to show that labour productivity contributes to project performance with a view to encouraging the adoption of labour productivity improvement techniques in construction project delivery. The objectives are to evaluate construction 
labour productivity in wall plastering activity and determine its relationship with project performance. The result of this study will assist construction managers to understand the cost and time implycations of loss in productivity so as to effectively plan to improve productivity in order to achieve project objectives.

\section{Review of Related Literature}

The term productivity has been in the front burner of the construction industry and other industries for a long time now. In the construction industry, it has received much attention and discussion within the past few decades and is still being discussed and researched. It has been widely used as a performance indicator to evaluate construction operations through the entire construction phase [11]. Construction companies have to track productivity continuously in order to gauge their performance capacity to maintain profitability and to prepare future bids [12]. According to Lindsay [13], productivity is defined as a measure of the ability to create goods and services from a given amount of labour, capital, materials, land, knowledge, time, or any combination of these. Studies describe it as the ratio of output to input $[13,14]$. Conversely, productivity has also been defined as the ratio of the quantity of input to the quantity of output $[15,16]$.

Measures of productivity can be examined in terms of the full range of production factors - capital, labour, intermediate goods, and services (including natural resources) or a single factor such as labour. In as much as productivity describes the output potential of a production process in relation to its inputs, it can be measured based on two broad categories of Single Factor Productivity such as Average Labour Productivity (ALP) and MultiFactor Productivity or Total Factor Productivity (TFP). While Single Factor Productivity measures the impact of one input (labour), Multi-Factor or Total Factor Productivity measures the impact of all inputs on output [17]. Tasks refer to specific construction activities such as block/brick work, wall plastering, concrete placement or structural steel erection and so on. Huang et al. [18] opine that tasklevel metrics are widely used in the construction industry. Most task-level metrics are single factor measures and focus on labour productivity. Attar et al. [1] maintain that at project sites contractors are often interested in labour productivity; they define it in one of the following two ways:

$$
\begin{aligned}
& \text { Labour Productivity }=\frac{\text { Output }}{\text { Labour Cost }} \\
& \text { Labour Productivity }=\frac{\text { Output }}{\text { Work - hour }}
\end{aligned}
$$

The study also observes that there is neither a consensus as to the meaning nor a universally accepted measure of productivity and that the inverse of labour productivity, man-hours per unit (unit rate) is also commonly used.

Various performance indicators have been used to measure project performance. Many of them are based on the frameworks developed by both public and private organisations. Key Performance Indicators (KPIs) are developed by KPI working group in UK while Project Performance Evaluation (PPE) is launched by Australian New South Wales Public Works Department [19]. It is, however, important to distinguish between performance indicators, performance measures, and performance measurement. According to Mbugua et al. [20], performance indicators specify the measurable evidence necessary to prove that a planned effort has achieved the desired result. They further observe that when indicators can be measured with some degree of precision and without ambiguity, they are called measures. However, when it is not possible to obtain a precise measurement, it is usual to refer to them as performance indicators. Idoro [21] considers the issue of performance indicators and measures by classifying parameters for measuring performance into two broad categories of subjective and objective parameters. The subjective parameters refer to the performance indicators while the objective parameters relate to the performance measures. It could, therefore, be concluded that quantitative/objective and qualitative/subjective indicators of project performance, no matter the terminology used are prominent in research studies with time and cost as the major parameters of objective measure of project performance. According to Idoro [21], two parameters of time-overrun and cost-overrun remained the prominent indicators of objective measurement of project outcome from the perspectives of previous studies. He, however, observes that these two parameters have their limitation because their values rely on the initial and final contract period or cost of a project. Nevertheless, the common assessment of the success of construction projects is that they are delivered on time, to budget, to technical specification, and meet client satisfaction [22]. The third parameter (quality) according to Idoro [21] is not a common objective parameter in research studies. In view of the agreement among researchers on the use of time and cost overruns as objective measures of project performance, these measures have been adopted in this study to assess the influence of productivity on project performance visà-vis wall plastering activity. It is clear that project cost and time overruns are prominent in previous studies as indicators of project performance, nevertheless, labour costs and time overruns being major 
components of project costs [23] could be regarded as indicators of project performance. However, performance measurement on the other hand is a systematic way of evaluating the inputs and outputs in manufacturing operations or construction activity and acts as a tool for continuous improvements [20].

There is a general agreement among researchers that delays in project delivery which are most times used interchangeably with time overruns results into cost overruns $[24,25]$. Construction delays and cost overruns although reported to be frequent occurrences in developing countries [26,27] have also been acknowledged to be a global phenomenon $[28,29]$. Studies on time and cost overruns of construction projects have identified various reasons for its occurrence which vary along with types of project, locations, sizes, and scopes [29]. Ramanathan et al. [30] discover that the causes of time and cost overruns identified from previous studies are classified into 18 categories namely; Finance-related, Project-related, Project Attributes, Owner/Client, Contractor, Consultant, Design-related, Coordination, Materials, Plant/Equipment, Labour/Manpower, Environment, Contract-related, Contractual Relationships, External, Changes, Scheduling \& Controlling and Governmental Relationship. While some of these studies clearly pinpoint labour productivity as one of the causes of time and cost overruns [6,31,32], others have associated labour productivity indirectly with cost and time overruns through factors affecting productivity under different headings [33,30]. Nevertheless, Haseeb et al. [33] remark that for the client, construction delay refers to the loss of revenue, lack of productivity, dependency on existing facilities, and lack of rentable facilities among other things. Kasimu [34] in a study of significant factors that causes cost overruns in building construction projects in Nigeria ranks lack of labour productivity $5^{\text {th }}$, out of eight other factors identified under the group of factors related to construction item. According to Ramanathan et al. [30] "it is clear from several studies and empirical evidence that project overruns comprising delays and cost overruns occur during the construction phase" and it is at this stage that the impact of labour productivity is eminent. Therefore, previous studies have always associated construction labour productivity with cost and time overruns of construction projects either directly or indirectly. However, its relationship with cost and time overruns has always been opined in relation to other factors through opinion surveys, i.e. studies that investigates empirically the relationship between construction labour productivity and cost and time overruns of construction projects are scarce. This study has been necessitated by this gap in literature.

\section{Research Methods}

Survey research design approach involving the use of project inventory sheet was adopted in this study. A purposive sampling of 180 completed public building projects executed by small and medium sized contractors was conducted. The buildings were mainly institutional buildings comprising of schools and law courts which were mostly bungalows. The sampling was based on projects that contain wall plastering activity with the same specification of cement-sand (1:4) $13 \mathrm{~mm}$ thick plastering finishing according to Building and Engineering Standard Method of Measurement 3 [35] and in which the observed working hours per day was 8 hours. Wall plastering activity was considered in the study because it is a common building activity associated with most public buildings in the study area, therefore availability of data would not be a problem. Two groups of variables namely: labour productivity and project performance were used to achieve the objectives of the study. Labour productivity consists of one variable, namely: labour productivity in wall plastering activity while project performance consists of two variables, namely: cost overrun and time overrun. Representatives of the contractors who executed the building projects, i.e. project supervisors/ engineers, were the respondents of the study. The study area is the South-South geo-political zone of Nigeria comprising of six geographical states namely; Akwa Ibom, Bayelsa, Cross River, Delta, Edo, and Rivers. The choice of the area is influenced by the reported increase in the volume of construction activities occasioned by the agitation of the people for sustainable development and the subsequent establishment of government ministry and para-statal to effect the development of the area. In addition, crude oil which is the nation's major source of foreign earnings is obtained from this area. The sampled building projects were evenly distributed across the states i.e. 30 in each state.

Two hypotheses were postulated in the attempt to determine the contribution of labour productivity to project performance. The hypotheses state as follows: $\mathrm{H}_{1}$ : There are no significant variations in construction labour productivity, time and cost overruns of completed public building projects across the states in the zone.

$\mathrm{H}_{2}$ : There are no significant relationship between construction labour productivity and time and cost performances of completed public building projects.

The project inventory sheet which served as the research instrument was structured to obtain data on: planned and actual duration of wall plastering activity measured in days; estimated and final direct 
labour cost of wall plastering activity measured in

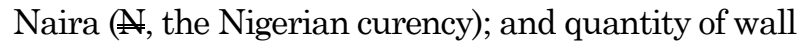
plastering activity in the projects measured in meter square $\left(\mathrm{m}^{2}\right)$. Data on daily productivity inputs and outputs of wall plastering activity in the public building projects sampled could not be obtained, therefore, this study adopted Equation 1 to analyse the overall task/activity labour productivity in each of the 180 building projects sampled. The quantity of wall plastering activity done in each of the projects measured in $\mathrm{m}^{2}$ was used as the output while the actual direct cost expended on labour in the activity was used as direct labour cost. Direct labour costs of plastering activity in this study refer to only the wages of the artisan and mate involved in the activity. This approach agrees with Chitkara [36] who states that another method for evaluating direct labour cost is to cover only salary and wages under direct cost and consider the balance expenses under indirect labour costs. The direct labour costs were adjusted for the computation of construction labour productivity to ensure that the same amount of wage for artisans and labourers applies. To achieve this, the highest wage recorded was used as the base wage for adjusting the labour cost. The adjustment was done using the principle of direct proportion where it is expected that the higher the wage rate the higher the labour cost. This is necessary to remove the influence of cost differentials in the wage rate on labour productivity because the metric used utilises labour cost as the input instead of man hours. The direct labour cost data obtained for the study were based on unit rate that excluded other expenses except wages for the item of work. This has no provision for incentives for higher productivity. The need to adjust the labour cost according to the wage rate was because the data were collected across six different states in the South-South geo-political zone of Nigeria. Some of the states differ in the wage rate paid to workers because of the standard and cost of living prevalent in the state and not because of the productivity of the worker. Therefore, differences in wage rate will influence the cost of labour when compared with other projects without necessarily having anything to do with productivity. The respondents also indicated that the daily working hours in all the projects sampled were eight hours. This information justifies the use of Equation 1 as an appropriate indicator of the overall labour productivity for the selected wall plastering activity. The cost and time overruns for the selected activity were computed as indicated below:

Cost overrun $=$

(Actual Direct Labour Cost-EstimetedDirect Labour Cost) EstimatedLabour Cost

Time overrun $=($ Actual Duration - Estimeted Duration $)$ Estimated Duration
The research hypotheses were tested using Analysis of Variance and Pearson Product Moment Correlation [47]. For the test, the significance of $\mathrm{F}$ and $\mathrm{r}$ were assessed at $95 \%$ confidence level that is $p$-value $\leq 0.05$ implies statistical significance while $\mathrm{p}$ values $>0.05$ implies statistical insignificance. The rule for the rejection of the hypothesis is that when the pvalue $>0.05$, the test fails to reject the hypothesis however, when the $\mathrm{p}$-value $\leq 0.05$, the test rejects the hypothesis.

\section{Results}

Results of the analysis of the data collected are presented as follows;

Analysis of Construction Labour Productivity, Cost and Time Overruns of Wall Plastering Activity

Construction labour productivity, time and cost overruns of wall plastering activity for 30 completed public building projects in each of the six states in South-South geo-political zone of Nigeria was analysed using the formula and procedure described in the research methodology. Table 1 shows the mean values for these variables of the study and how they were computed. To facilitate comparison with previous studies in the country, the mean value of construction labour productivity of wall plastering in South-South of Nigeria is converted to $\mathrm{m}^{2} / \mathrm{hr}$ and $\mathrm{m}^{2}$ per day for an eight hours working day involving a gang comprising a plasterer and mate. The conversion is carried out as shown below:

$6335.50 /(1772319.68 / 6000 \times 8)=2.68 \mathrm{~m}^{2} / \mathrm{hr}=2.68$ $\mathrm{x} 8=21.45 \mathrm{~m}^{2}$ per day.

The result shows that average values of construction labour productivity, percentage cost and time overruns of public building projects in the zone are $2.68 \mathrm{~m}^{2} / \mathrm{hr}, 14.09 \%$ and $7.35 \%$ respectively.

\section{Test for Variation in Construction Labour Productivity of Wall Plastering Activity among Six Geographical States in South-South of Nigeria}

Construction labour productivities in wall plastering activity for the completed building projects in the study area were computed as described earlier. Analysis of variance test was conducted to test for variation in labour productivities in the completed building projects executed across six geographical states in South-South of Nigeria. Table 2 shows the result of the test. The result indicates that there is significant variation in construction labour productivities for public building projects executed across 
Table 1. Construction Labour Productivity, Cost and Time Overruns of Wall Plastering Activity in South-South of Nigeria

\begin{tabular}{|c|c|c|c|c|c|c|c|c|c|c|}
\hline A & B & $\mathrm{C}$ & $\mathrm{D}$ & $\mathrm{E}$ & $\mathrm{F}$ & G & $\mathrm{H}$ & I & $\mathrm{J}$ & $\mathrm{K}$ \\
\hline \multirow[t]{2}{*}{ States } & \multirow[t]{2}{*}{$\mathrm{N}$} & $\begin{array}{l}\text { Output } \\
\left(\mathrm{m}^{2}\right)\end{array}$ & $\begin{array}{l}\text { Actual } \\
\text { Labour } \\
\text { Cost }(\mathbb{N})\end{array}$ & $\begin{array}{l}\text { Adj. Actual } \\
\text { Labour } \\
\text { Cost ( }) \\
\end{array}$ & $\begin{array}{c}\text { Estimated } \\
\text { Labour Cost } \\
(\nexists)\end{array}$ & $\begin{array}{c}\text { Planned } \\
\text { Duration } \\
\text { (days) }\end{array}$ & $\begin{array}{c}\text { Actual } \\
\text { Duration } \\
\text { (days) }\end{array}$ & $\begin{array}{c}\text { PRDTY } \\
\left(\mathrm{m}^{2} /\right)^{x} \\
1000\end{array}$ & $\begin{array}{c}\text { Cost } \\
\text { Overrun } \\
(\%)\end{array}$ & $\begin{array}{c}\text { Time } \\
\text { Overrun } \\
(\%)\end{array}$ \\
\hline & & Mean & Mean & Mean & Mean & Mean & Mean & Mean & Mean & Mean \\
\hline AKS & 30 & 2310 & 38410 & 594302 & 342 & 22.20 & 23.30 & 3.89 & 10. & 6.25 \\
\hline BYS & 30 & 7632.33 & 1578644.77 & 209668 & 1400 & 32.23 & 35.57 & 3.53 & 17 & 10.27 \\
\hline CRS & 30 & 3451.24 & 603128.87 & 928199 & 544 & 23.70 & 24.23 & 3.76 & 12.89 & 3.75 \\
\hline DLS & 30 & 2823.83 & 600612.82 & 802956.14 & 522378.83 & 26.07 & 28.37 & 3.49 & 15.49 & 9.01 \\
\hline EDS & 30 & 8863.76 & 1703717.20 & 2474426.06 & 1510624.87 & 36.97 & 39.73 & 3.64 & 13.42 & 4.22 \\
\hline RVS & 30 & 12931.81 & 2642169.80 & 3737351.36 & 2351116.67 & 42.83 & 47.17 & 3.39 & 15.20 & 10.61 \\
\hline Total & 180 & 6335.50 & 1252063.44 & 1772319.68 & 1111952.17 & 30.67 & 33.06 & 3.62 & 14.09 & 7.35 \\
\hline
\end{tabular}

*AKS = Akwa Ibom; BYS = Bayelsa; CRS = Cross River; DLS = Delta; EDS = Edo; RVS = Rivers; E = Adjusted Actual Labour Cost = Total Labour Cost/Total Labour Wage x 6000 (6000 is the base labour wage of 4000 for skilled and $\$ 2000$ for unskilled); I = Projects' Labour Productivity in Wall Plastering = C/E x 1000; $\mathrm{J}=$ Projects' Cost Overrun in Wall Plastering $=(\mathrm{D}-\mathrm{F}) / \mathrm{F} \times 100 ; \mathrm{K}=$ Projects' Time Overrun in Wall plastering $=(\mathrm{H}-\mathrm{G}) / \mathrm{G} \times 100$

NB: The figures in the table are mean values for 30 projects in each state therefore the key above will not give the exact figures in the table but only illustrates how they were computed.

Table 2. ANOVA Test for Variation in Construction Labour Productivity of Wall Plastering Activity in South-South of Nigeria

\begin{tabular}{lrrrrrrc}
\hline & Sum of Squares & \multicolumn{1}{c}{ df } & Mean Square & F & F Critical & p-value & Decision \\
\hline Between Groups & 5.096 & 5 & 1.019 & 2.552 & 2.266 & 0.029 & significant \\
Within Groups & 69.502 & 174 & 0.399 & & & & \\
Total & 74.598 & 179 & & & & & \\
\hline
\end{tabular}

Table 3. ANOVA Test for Variation in Time and Cost Overruns in Wall Plastering Activity in South-South of Nigeria

\begin{tabular}{llrrrrrrr}
\hline $\begin{array}{c}\text { Parameters } \\
\text { Tested }\end{array}$ & & $\begin{array}{c}\text { Sum of } \\
\text { Squares }\end{array}$ & df & $\begin{array}{c}\text { Mean } \\
\text { Square }\end{array}$ & F & F critical & p-value & Decision \\
\hline Project Time & Between Groups & 1374.055 & 5 & 274.811 & 1.318 & 2.266 & 0.258 Not significant \\
Overruns & Within Groups & 36268.785 & 174 & 208.441 & & & & \\
& Total & 37642.840 & 179 & & & & & \\
\hline Project Cost & Between Groups & 788.607 & 5 & 157.721 & 1.902 & 2.266 & 0.096 Not significant \\
Overruns & Within Groups & 14432.016 & 174 & 82.943 & & & & \\
& Total & 15220.623 & 179 & & & & & \\
\hline
\end{tabular}

the states that constitutes the South-South geopolitical zone of Nigeria $(\mathrm{F}=2.552>\mathrm{F}$ critical $=$ 2.266 or $\mathrm{p}=0.029<0.05)$. Therefore, the test rejects the hypothesis of no significant variation in construction labour productivity across the states in the zone.

Test for Variation in Project Time and Cost Overruns in Wall Plastering Activity among Six Geographical States in South-South of Nigeria

Time overruns experienced in wall plastering activity for the completed building projects in the study area were computed as earlier described. Analysis of variance test was performed to test for variation in the time overruns of building projects across six states in South-South geo-political zone of Nigeria. Table 3 shows the result of the test and it indicates that there is no significant variation in the time overruns of wall plastering activity for public building projects executed across the states that constitutes the South-South geo-political zone of
Nigeria $(F=1.318>F$ critical $=2.266$ or $p=0.258>$ 0.05). Therefore, the test fails to reject the hypothesis of no significant variation in the time overruns of completed building projects across the states in the zone.

Similarly, cost overruns observed in wall plastering activity for the completed building projects in the study area were computed as earlier described. Analysis of variance test was performed to test for variation in the cost overruns of building projects across six states in South-South geo-political zone of Nigeria. Table 3 also shows the result of the test which indicates that there is no significant variation in the cost overruns of wall plastering activity for public building projects executed across the states that constitutes the South-South geo-political zone of Nigeria $(F=1.902>F$ critical $=2.266$ or $p=0.096>$ 0.050). Therefore, the test fails to reject the hypothesis of no significant variation in the cost overruns of completed building projects across the states in the zone. 


\section{Relationship between Labour Productivity of Wall Plastering and Project Performance}

To determine the relationship between labour productivity and project performance in terms of cost and time overruns in wall plastering activity, the second research hypotheses was tested. Pearson Product Moment Correlation was used to test the hypothesis as described in the research methods. The result of the test is presented in Table 4.

The result shows that $\mathrm{r}=-0.639$ and $-0.706 ; \mathrm{p}=$ 0.000 and 0.000 for cost and time overruns respectively. Therefore; the hypotheses that, there is no statistically significant linear relationship between construction labour productivity and the cost and time overruns in wall plastering activity were rejected. This result indicates that there is a strong negative correlation between construction labour productivity and cost and time overruns of wall plastering activity for the building projects sampled. In other words, the higher the productivity of construction labour, the less the cost and time overruns.

\section{Discussion of Results}

This study investigates 180 purposively sampled completed public building projects to determine the relationship between construction labour productivity and project performance which is defined by time and cost overruns. Provided that the same normal eight working hours were observed during the construction stage of the building projects as indicated by the respondents of the study and the labour costs were adjusted to ensure that the same amount of wage for artisans and labourers applies, a higher value indicated by the productivity measure will imply higher labour productivity and vice versa. Similarly, at a constant output the lower the labour cost incurred the higher the productivity and vice versa. Cost overruns normally should arise as a result of lower productivity caused by factors or situations on the site which have affected labour productivity and for which the contractor has to pay more in order to accomplish the task. On the other hand, cost overruns could also arise as a result of inaccurate labour cost estimates. Assuming that both the time and cost overruns were not as a result of inaccurate estimation or reasons other than the productivity of the project in terms of the selected task as indicated by the respondent of the study, then the productivity metrics adopted will indicate productivity in relation to project performance of cost and time overruns.

The result indicates that the average construction labour productivity in wall plastering activity is approximately equal to $2.68 \mathrm{~m}^{2} / \mathrm{hr}$ which is equivalent to $21.45 \mathrm{~m}^{2}$ per day. This shows that there is improvement in labour productivity over the years when compared to Olomolaiye and Ogunlana [37] where it was reported that the average observed output in an 8 hours per day schedule for wall plastering activity was $9.31 \mathrm{~m}^{2}$ per day. This is supported by the observation made by Otti [38] that there is improvement in the performance of the construction industry from 2008 due to better project management, improved contract method and the involvement of clients and contractors in project delivery. In addition, according to Odesola [39] it is held generally in the zone that for wall plastering the norm is that two wall partitions should constitute a day's job under normal situations. Therefore, there appears to be a baseline output in the zone to monitor and improve labour productivity over the years. However, the result agrees with the findings of Odesola [39] which reports that the average productivity for wall plastering in South-South of Nigeria is $2.70 \mathrm{~m}^{2} / \mathrm{hr}$ which is equivalent to $21.60 \mathrm{~m}^{2}$ per day.

Ramanathan et al. [30] observe that studies on the effects of factors affecting cost and time overruns are not comparable and that they differ based on location. Therefore, comparison with similar studies in Nigeria will be made. Average percentage cost and time overruns of $14.09 \%$ and $7.35 \%$ obtained in the study differ with the findings of Ijigah et al. [40] where it is reported to be $29.21 \%$ and $23.76 \%$ respectively for 25 Millennium Development Goal's projects in Abuja. The difference may have stemmed from the fact that the overruns reported in this study resulted from a single activity of wall plastering whereas the one from previous study emanated from the project as a whole. In addition, wall plastering is regarded as a finishing trade of which sequencing problems and lack of clear and adequate information on the manner in which the work should proceed have been identified as the main causes of delays in

Table 4. Test of Correlation between Construction Labour Productivity and Cost and Time Overruns of Wall Plastering Activity

\begin{tabular}{lrrrr}
\hline Parameters correlated & $\mathrm{N}$ & Mean & $\mathrm{R}$ & $\mathrm{p}$-value \\
\hline Construction labour productivity & 180 & 3.62 & -0.639 & 0.000 \\
Activity cost-overrun & 180 & 14.09 & & Decision \\
Construction labour productivity & 180 & 3.62 & -0.706 & 0.000 \\
Activity time-overrun & 180 & 7.35 & & Significant
\end{tabular}

${ }^{*} \mathrm{~N}=$ Number of completed building projects, $\mathrm{r}=$ correlation value 
its execution [39]. In the same vein, some of the plastering activities are carried out on internal wall surfaces excluded from the effect of weather. Therefore, with the adoption of adequate labour productivity management strategies, the cost and time overruns in this activity should be expected to be lower compared to other activities exposed to the uncontrollable effects of weather which may have contributed to the overall high cost and time overruns recorded in a project as a whole.

The result also shows that there is significant variation in construction labour productivities in the wall plastering activities among six geographical states that make up the South-South geo-political zone of Nigeria. Although this is in consonance with the findings of Kaming et al. [6] that there is significant regional variation in production output, skill, motivation of artisan, and operative's productivity among the regions in Indonesia, it however, differs with the findings in Odesola [39] that there is no significant variation in construction labour productivity in South-South zone of Nigeria. The possibility of inaccurate project records as opposed to the determination of actual construction labour productivities through work study methods [39] and the different productivity metrics of $\mathrm{m}^{2} / \mathrm{N}$ and $\mathrm{m}^{2} / \mathrm{hr}$ adopted in the two studies may have accounted for the difference in the outcomes of the studies. Furthermore, the non significant variation in the time and cost overruns reported across the states is indicative of the similarity in the type of buildings investigated in the study together with the commonality reported across the states in the study area. Researchers have noted that many factors relate to delay and cost overruns and vary along with types of project, locations, sizes, and scopes [29,41]. In the same vein, Odesola [39] observes that even though the country is reputed for its vast cultural and ethnic diversity, the geo-political divisions tend to present some commonality in terms of contiguity, linguistics, ethnicity, and cultural practices. Similarly, Oyelere [42] reports that there is no evidence of significant disparities in labour market outcome across geopolitical regions in Nigeria. Therefore, similarity in the type of buildings investigated in the study together with the commonality reported across the states in the study area justifies the similarity in the time and cost overruns observed in the study. In addition, it could also be implied that no difference in time and cost overruns could mean that the relative effects of factors responsible for overruns in the zone are likely to be the same.

The result finally shows that there is a strong negative correlation between labour productivity and cost and time performance of wall plastering activity. This result implies that construction labour productivity has a positive influence on the performance of public building projects in terms of both cost and time when the effects of other factors are assumed to be held constant. This finding agrees with the finding in similar studies that productivity is one of the project performance indicators $[20,43,44]$. However, the relationship between labour productivity and key performance measures has continued to generate concern in studies relating to cost and time overruns of construction projects without much empirical evidence. Kaming et al. [6] and Chan and Kumaraswamy [10] have opined that construction industries in many developed and developing countries suffer from delays and cost overruns due to labour productivity problems. Therefore, the findings of this study lay credence to the suggestions in these previous studies that construction labour productivity has a strong negative relationship with cost and time overruns of public building projects in Nigeria. This also agrees with the conclusion of Ameh and Osegbo [45] that significant negative relationship exist between time overrun and labour productivity in construction sites in Nigeria. In the same vein, the findings of this study support the opinion of Hanna et al. [46] that the relationship between productivity and project cost overrun is inversely proportional.

\section{Conclusion}

From the finding of this study, it is concluded that when project locations are similar in terms of linguistics, ethnicity, and cultural practices, project performances in terms of cost and time across the locations tend to be about the same. Consequently, it is concluded that the relative effects of factors affecting cost and time overruns in the study area are likely to be the same. It is also concluded that the cost and time performances of public building projects in Nigeria are positively influenced by labour productivity when the effects of other factors are held constant. Therefore, improvement in labour productivity of the building industry in South-South of Nigeria will result in better performances of public building projects. In the same vein, the menace of abandoned public building projects could be ameliorated through enhancement of construction labour productivity. In view of this, the study recommends that construction managers in addition to ensuring accurate labour estimates should identify and mitigate the adverse effects of negative factors affecting construction labour productivity and promote the ones that enhance productivity for effective delivery of public construction projects in terms of cost and time performances. This could be achieved by conducting productivity studies on construction sites, adequate supervision of artisans and the use of monetary and non-monetary incentives to motivate workers for higher productivity. 


\section{Acknowledgement}

The author acknowledges the Tertiary Education Trust Fund (TETFUND) of Nigeria for the Doctoral study grant given to the author which has contributed to the success of this research work.

\section{References}

1. Attar, A.A., Gupta, A.K., and Desai, D.B., A Study of Various Factors Affecting Labour Productivity and Methods to Improve It, IOSR Journal of Mechanical and Civil Engineering (IOSR-JMCE), 1(3), 2012, pp. 11-14.

2. Park, H., Thomas, S.R., and Tucker, R.L., Benchmarking of Construction Productivity, Journal of Construction Engineering and Management, 131(7), 2005, pp. 772-778.

3. Veiseth, M., Rostad, C.C., and Andersen, B., Productivity and Logistic in the Construction Industry - What can the Construction Industry Learn from Stationary Industry? Paper Presented at NORDNET, 2003, Available at: http://goo.gl/w5h3q, assessed 25 September, 2013.

4. Hewage, K.N. and Ruwanpura, J.Y., Carpentry Workers Issues and Efficiencies Related to Construction Productivity in Commercial Construction Projects in Alberta, Canadian Journal of Civil Engineering, 33(8), 2006, pp. 1075-1089.

5. Lawal, P.O., Capacity Utilization of Construction Craftsmen in Public Sector in North Central Zone of Nigeria, Ph.D. Thesis, University of Jos, Jos, Nigeria, 2008.

6. Kaming, P.F., Olomolaiye P.O., Holt G.D., and Harris, F.C., Factors Influencing Craftsmen's Productivity in Indonesia. International Journal of Project Management, 15(1), 1997, pp. 21-30.

7. Hendrickson, C. and Au, T., Project Management for Construction: Fundamentals Concepts for Owners, Engineers, Architects and Builders, 2003, Available at: Http.//www.ce.com. edu./ pmbook/10, accessed on 25 September, 2013.

8. Aibinu, A.A. and Jagboro, G.O., The Effects of Construction Delays on Project Delivery in Nigerian Construction Industry, International Journal of Project Management, 20, 2002, pp. 593-599.

9. Nwachukwu, C.C., Ibeawuchi, E., and Okoli, M.N., Project Management Factor Indexes: A Constraint to Project Implementation Success in the Construction Sector of a Developing Economy, European Journal of Scientific Research. 43(3), 2010, pp. 392-405.

10. Chan, D.W.M. and Kumaraswamy, M.M., Compressing Construction Durations: Lessons Learned from Hong Kong Building Projects, International Journal of Project Management, 20, 2002, pp. 23-35.
11. Bai, Y. and Kim, S., Development of a Wireless Real-Time Productivity Measurement System for Rapid Construction Operations, A Report on Research Sponsored by Kansas University Transportation Research Institute, Kansas Department of Transportation and Federal Highway Administration, 2008, Available at: http:/gradworks.umi.com/3336422.pdf, accessed 25 September, 2013.

12. Ghanem, A.G. and Abdelrazig, Y.A., A Framework for Real-Time Construction Project Progress Tracking, Proceedings of the $10^{\text {th }}$ Biennial International Conference on Engineering, Construction, and Operations in Challenging Environments, League City/Houston, TX, United States, 2006, p. 112.

13. Lindsay, C., Labour Productivity: Special Feature. Labour Market Division, Office for National Statistics, 2004, pp. 447-453, Available at: http://www.ons.gov.uk/ons/rel/lms/labour-markettrends--discontinued-/volume-112--no--11/labourproductivity.pdf, accessed on 25 September, 2013.

14. Schreyer, P., Measuring Productivity, Conference on Next Steps for the Japanese SNA, Tokyo, 2005, Available at: http://www.esri.go.jp/jp/workshop/050325/050325 paper06.pdf, accessed on 26 September, 2013.

15. Choi, J. and Minchin Jr., R.E., Workflow Management and Productivity Control for Asphalt Pavement Operations, Canadian Journal of Civil Engineering, 33, 2006, pp. 1039-1049.

16. Song, L. and AbouRizk, S.M., Measuring and Modelling Labour Productivity using Historical Data, Journal of Construction Engineering and Management, 134(10), 2008, pp. 786-794.

17. Crawford P. and Vogl B., Measuring Productivity in the Construction Industry, Building Research and Information, 34(3), 2006, pp. 208-219.

18. Huang, A.L., Chapman, R.E., and Butry, D.T., Metrics and Tools for Measuring Construction Productivity: Technical and Empirical Considerations, U.S. Department of Commerce National Institute of Standards and Technology, Gaithersburg, Maryland, 2009.

19. Cheung, S.O., Suen, H.C.H., and Cheung, K.K.W., PPMS: A Web-Based Construction Project Performance Monitoring System, Automation in Construction, 13, 2004, pp. 361 - 376.

20. Mbugua, L.M., Harris, P., Holt, G.D., and Olomolaiye, P.O., A Framework for Determining Critical Success Factors Influencing Construction Business Performance, 1999. In: Hughes, W. (ed), Proceedings of $15^{\text {th }}$ Annual Association of Researchers in Construction Management (ARCOM) Conference, Liverpool John Moores University, September 5-7, Reading, 1, pp. 255264. 
21. Idoro, G.I., The Influence of Project Documents on the Outcome of Construction Projects Procured by Traditional Contract in Nigeria, Journal of Construction in Developing Countries. 17(1), 2011, pp. 151-173.

22. Michell, K., Bowen, P., Cattell, K., Edward, P., and Pearl, R., Stakeholder Perceptions of Contractor Time, Cost and Quality Management on Building Project, Proceeding of the CIB World Building Conference on Construction for Development, Cape Town, South Africa, 2007, 14-18 May, pp. 231-240.

23. Kazaz, A., Manisali E., and Serdar, U., Effect of Motivational Factors on Construction Workforce Productivity in Turkey, Journal of Civil Engineering and Management, 14(2), 2008, pp. 95-106.

24. Assaf, S.A. and Al-Hejji S., Causes of Delay in Large Construction Project, International Journal of Project Management. 24(4), 2006, pp. 349357.

25. Al- Gahtani, K.S. and Mohan, S.B., Total Float Management for Delay Analysis, Journal of Cost Engineering, 49(2), 2007, pp. 32-37.

26. Toor, S. U. and Ogunlana, S. O., Problems Causing Delays in Major Construction Projects in Thailand, Journal of Construction Management and Economics, 26(4), 2008, pp. 395-408.

27. Pourrostam, T., Ismail, A., and Mansounejad, M., Identification of Success Factors in Minimizing Delays on Construction in IAU-Shoushtar-Iran, Periodicals of Applied Mechanics and Materials, 94-96, 2011, pp. 2189-2193.

28. Majid, I.A., Causes and Effects of Delays in Aceh Construction Industry, Unpublished MSc. Dissertation, University of Malaysia, Malaysia, 2006.

29. Le-Hoai, L., Lee, Y.D., and Lee, J.Y., Delay and Cost Overruns in Vietnam Large Construction Projects: A Comparison with other Selected Countries', KSCE Journal of Civil Engineering, 12(6), 2008, pp. 367-377.

30. Ramanathan, C., Narayanan, S.P., and Idrus, A.B., Construction Delays Causing Risks on Time and Cost - a Critical Review, Australasian Journal of Construction Economics and Building, 12(1), 2012, pp. 37-57.

31. Odeh, A.M. and Battaineh, H.T., Causes of Construction Delay: Traditional Contracts, International Journal of Project Management, 20, 2002, pp. 67-73.

32. Murray, M., Seif, M., and Umaru, W., Causes of Project Delay in Nigerian Construction Industry, European Journal of Civil Engineering and Architecture, 10, 2013, pp. 1-7, Available at http://bellpress.org/Journals/index.php/EJCEA/a rticle/download/893/133, assessed 25 September, 2013.
33. Haseeb, M., Xinhai-Lu, Bibi, A., Maloof-UdDyian, and Rabbani, W., Causes and Effects of Delays in Large Construction Projects of Pakistan, Kuwait Chapter of Arabian Journal of Business and Management Review, 1(4), 2011, pp. 18-42.

34. Kasimu, M.A., Significant Factors that Causes Cost Overruns in Building Construction Project in Nigeria, Interdisciplinary Journal of Contemporary Research in Business, 3(11), 2012, pp. 775-780.

35. Building and Engineering Standard Method of Measurement 3, third edition, The Nigerian Institute of Quantity Surveyors, Lagos, 2008.

36. Chitkara, K.K., Construction Project Management: Planning, Scheduling and Controlling, second edition, Tata McGraw Hill Education Private Limited, New Delhi, 2011.

37. Olomolaiye P.O. and Ogunlana S.O., An Evaluation of Production Outputs in Key Building Trades in Nigeria, Construction Management and Economics, 7, 1989, pp. 75-86.

38. Otti, V.I., Engineering Implication for Millennium Development Goals in Revamping and Sustaining Nigeria Economy, International Journal of Engineering Research and Applications (IJERA), 2(2), 2012, pp. 1373-1377.

39. Odesola, I.A., Construction Labour Productivity of Masonry Operations in South-South of Nigeria, Unpublished Ph.D. Thesis, Department of Building, University of Uyo, Nigeria, 2012.

40. Ijigah, E.A., Ogunbode, E.B., and Ibrahim, M.O., Analysis and Prediction of Cost and Time Overrun of Millennium Development Goals (MDGS) Construction Projects in Nigeria, Developing Country Studies, 2(10), 2012, pp. 140-147.

41. Memon, A.H., Rahman, I.A., and Abdul-Azis, A.A., Preliminary Study on Causative Factors Leading to Construction Cost Overrun, International Journal of Sustainable Construction Engineering and Technology, 2(1), 2011, pp. 5771.

42. Oyelere, R.U., Disparities in Labour Market Outcomes Across Geo-political Regions in Nigeria: Fact or Fantasy? Georgia Institute of Technology and Institute for the Study of Labour (IZA) Discussion Paper No. 3082, 2007, Available at: http://ftp.iza.org/dp3082.pdf, assessed 25 September, 2013.

43. Takim, R. and Akintoye, A., Performance Indicators for Successful Construction Project Performance. In: Greenwood, D.J. (Ed.), 18th Annual Association of Researchers in Construction Management (ARCOM) Conference, 2-4 September, University of Northumbria, 2, 2002, pp. 545-555. 
44. Takim, R., Akintoye, A., and Kelly, J., Performance Measurement Systems in Construction. In: Greenwood, D.J. (Ed.), 19th Annual Association of Researchers in Construction Management (ARCOM) Conference, 3-5 September 2003, University of Brighton, 1, 2003, pp. 423-432.

45. Ameh, O.J. and Osegbo, E.E., Study of Relationship between Time Overrun and Productivity on Construction Sites, International Journal of Construction Supply Chain Management, 1(1), 2011, pp. 56-67.
46. Hanna, A.S., Chang, C., Sullivan, K.T., and Lackney, J.A., Impact of Shift Work on Labour Productivity for Labour Intensive Contractor, Journal of Construction Engineering and Management, 138(3), 2008, pp. 197-204.

47. Pallant, J., SPSS Survival Manual - A Step by Step Guide to Data Analysis using SPSS for Windows, third edition, McGraw Hill, Open University Press, Maidenhead, 2007. 